DOI

http://dx.doi.org/10.1590/2236-463320151011

0 Conselho Geral da Província do Pará e a definição da política indigenista no Império do Brasil (1829-31)

\section{General Council of the Province of Pará and the Definition of the Indigenist Politics in the Empire of Brazil (1829-31)}

\author{
André Roberto de A. Machado \\ Universidade Federal de São Paulo, \\ São Paulo - SP, Brasil \\ e-mail: andre.machado@unifesp.br
}

\begin{abstract}
The objective of this article is to demonstrate how General Council of the Province of Grão-Pará discussed and proposed projects that aimed to intervene in the indigenist politics in operation, between 1829 and 1831. Prioritily, it is sought to expose as this theme was vital for the province, which explains largely why the indigenous issue was a subject that deserved one of the largest numbers of projects and interventions presented in General Council during the studied period. At the same time it is sought to understand the tensions among the local and national interests in the definition of an indigenist politics, reminding that just in 1845 a general law will be formulated for all the Indians of the Empire of Brazil.

\section{Resumo}

0 objetivo deste artigo é demonstrar como o Conselho Geral da Província do Grão-Pará debateu e propôs projetos que visavam intervir na política indigenista em vigor, entre 1829 e 1831. Em um primeiro plano, busca-se expor como este tema era vital para a província, o que em grande medida explica porque a questão indígena foi um assunto que mereceu um dos maiores números de projetos e intervenções apresentados no Conselho Geral no período estudado. Ao mesmo tempo, busca-se compreender as tensões entre os interesses locais e nacionais na definição de uma política indigenista, lembrando que apenas em 1845 se formulará uma lei geral para todos os índios do Império do Brasil.
\end{abstract}

Keywords

General Council, Indians, Grão-Pará, Indigenist politics

Palavras-chave

Conselho Geral, índios, Grão-Pará, Política Indigenista research. A preliminary and summarized version of this text was published in the Annals of the $27^{\circ}$ Simpósio Nacional de História - ANPUH. 
2

SAMPAIO, Patrícia Maria de Melo. Política Indigenista no Brasil Imperial. In: GRINBERG, Keila; SALLES, Ricardo. História do Brasil Imperial. Volume 1 - 1808-1831. 2a edição. Rio de Janeiro: Civilização Brasileira, 2011. p.175-206.

3

MONTEIRO, John. Tupis, tapuias e historiadores: estudos de história indígena e indigenismo. 2001. 233 fls. Dissertation (Habilitation/ Livre-docente). Instituto de Filosofia e Ciências Humanas, Universidade Estadual de Campinas, Campinas, 2001.

4 CUNHA, Manuela Carneiro da. Prólogo. IN: (org.). Legislação indigenista no século XIX: uma compilação. São Paulo: Editora da Universidade de São Paulo, 1992. p.9-11.

DANTAS, Mônica Duarte (org.) Revoltas, Motins, Revoluções: homens livres pobres e libertos no Brasil do século XIX. São Paulo: Alameda, 2011. Introdução.

6

LOPES, José Reinaldo de Lima. Iluminismo e Jusnaturalismo no ideário dos juristas da primeira metade do século XIX. IN: JANCSÓ, István (org.) Brasil:formação do Estado e da nação. São Paulo: Hucitec, 2003. p.200.
It was only in 1845 with the approval of the "Rule about the catechism missions and Indian civilization" that the Empire of Brazil now had a general law for the Indians valid in all the dominion. A law that, moreover, would remain the unique of its type during all the Empire.

Patricia Sampaio, studying the new law, attracted attention for the fact that it would not just promote the catechism with the new rule. On the contrary, Sampaio demonstrated that although the catechism being a central aspect of the "Rule of Missions" the entire administration was in charge of civilian authorities: a General Director of every province named directly by the central power, and Village Directors these were indicated by the General Director to the Provincial President. For these authorities was reserved the decision about a series of actions that composed the multifaceted characteristic of the new law. In this sense the new rule secured land for the Amerindians that were incorporated to the culture of the White men, simultaneously it created mechanisms so that the land of these people could be rent. In the same matter, at the core of the law was the preoccupation about the control and discipline of the Indian labor, promoting its engagement on several activities under salaried employment of a third party and under the command of Village Directors. ${ }^{2}$ Incorporation, land and work: a triad that would always go along with the discussion about the indigenous issue in the Empire of Brazil. In addition, of course, of the talk of those who the only possible treatment for these people was the eradication, given its supposedly failure for civilization. ${ }^{3}$

The nonexistence, until 1845, of a valid law in all the territory of the Empire, who regulate the relationship with the Indians maintained the statement of Manuela Carneiro da Cunha, that during all that period they lived a "legislative void" regarding this question. The statements of Cunha imply that this flaw would be caused specially by the supposedly loss of importance of the theme. For her the Indians in the Nineteenth Century would be mainly a land issue, with merely few exceptions in the territory where their labor was still relevant. ${ }^{4}$

Indeed, there was not until 1845 a general law for the entire Empire that established a policy for the Indians in the entire territory, but it doesn't look like the lack of significance of the theme could be the explanation of this fact. Instead, it's necessary to think that one of the most difficult duties of the builders of this new State was to found a new legal base. Several were the urgent themes to be disciplined by the law and looks like it was clear for the men of the period, since very early, that it would take many years to do so. As noted by Mônica Dantas, the very Constituent Assembly took the precaution of create a law in October 20, 1823 that defined that as long as there were no new legislation in the Empire, laws and other rules edited in Portugal until 1821 would still be valid in national territory. ${ }^{5}$ This, in truth, ended being the current practice too as a way to remedy a number of gaps for which there was no legal definition yet. As summarized by José Reinaldo Lopes:

Thus, as we don't do daily things overnight, the independent first years [of the Empire of Brazil] were of intimacy with a complex order, which kept foreign (Portuguese) and colonial devices (or pre-liberal). ${ }^{6}$

In this regard, many sensitive themes did not had a fast legal regulation, as they do not always were in the center of the discussion. To exemplify this, Tâmis Parron points to the trade and slavery of black people in 
PARRON, Tamis. A politica da escravidão no Império do Brasil (1826-65). Rio de Janeiro: Civilização Brasileira, 2011. Cap. 1.

GODOY, Scarlett O'Phelan. Los diputados peruanos en las Cortes de Cádiz y el debate sobre el tributo, la mita y la ciudadanía indígena. Revista de História Iberoamericana, v.5, n.1, 2012. LARSON, Brooke. Trials of Nation Making: Liberalism, Race and Ethnicity in the Andes, 1810-1910. New York: Cambridge, 2004. For a comparision between the process in Cádiz and the Courts of Lisbon regarding the Indian question see SANTOS, Raquel Dani Sobral. $A$ construção do estatuto do cidadão para os índios do Grão-Pará (1808-22). 2014. 121 fls. Thesis (Master's Degree in History). Faculdade de Filosofia, Letras e Ciências Humanas, Universidade de São Paulo, São Paulo, 2014. Cap. 2.

9

Look for ZANY, Francisco José Ricardo. Projeto para os índios do Grão-Pará. IN: Diário das Cortes, 1821/1822. Sessão de 26 de Agosto de 1822. Available at: <http://debates.parlamento.pt>. Accesed in: January 09, 2015.

10

About the projects of the Indians in the Courts of Lisbon and the debate of this matter, see BOEHER, George. Some Brazilian Proposals to the Cortes Gerais 1821-23, on the Indian Problem. In: COLÓOUIO INTERNACIONAL DE ESTUDOS LUSOBRASILEIROS, 3., Lisboa. Actas do 30 Colóquio Internacional de Estudos Luso-brasileiros. Lisboa: [inserir editora], 1960. v.ll, p.201-209; de MOREIRA NETO, Carlos de Araújo. Índios da Amazônia: de maioria a minoria (1750-1850). Petrópolis: Vozes, 1988; de SPOSITO, Fernanda. $\mathrm{Nem}$ cidadãos, nem brasileiros: indígenas na formação do Estado nacional brasileiro e conflitos na província de São Paulo (1822-1845). São Paulo, Alameda: 2012. p.65-71; e de SANTOS, Raquel Dani Sobral. Op. Cit., cap. 3.

11

Constituição Portuguesa de 23 de Setembro de 1822. Available at: <http://www.fd.unl.pt/Anexos/ Investigacao/7511.pdf> Accessed in: January 09, 2015 the Empire of Brazil, a matter that looks to be of indisputable importance. As pointed by Parron, excluding the strong clashes between 1826 and 1827 of the international treaty about the end of the slave trade in 1831, this theme was secondary in the registered debates on the annals of the Parliament at least until 1834. In addition to the bet that the silence was a form to keep the established situation, Parron clarifies other reason: the efforts were centered in the very definition of the political game, in the establishment of rules for the running of the institutions.' It should not be forgotten that this too was an aspect that lacked urgent legal definition for many fields.

Despite not being constituted a general law until 1845, the debate about an Indigenist policy was constant during the Nineteenth Century. On the Court of Lisbon were sent projects for this matter from São Paulo, Pernambuco, Pará and Bahia, four great provinces, what on its own demonstrate the importance of the theme. It is truth too that the dimensions of this debate were much more different than what occurred in the Cádiz Cortes, a comparison that seem very valid for the enormous influence that the Spanish Constitutional Assembly had over the later Portugal experience.

At Cádiz the Indians' question had important developments with the explicit acknowledgement of this group as Spanish citizens, action that featured the pressure from the American deputies interested in a growth of the number of seats from the New World in the European parliament. Directly resulting from this, the congress of Cádiz ended the forced labor of Indians in the Hispanic America under the assumption of tributes, as the mita. This is a decision that draws attention because the end of the tributes was justified as necessary to match the condition of the Indian citizens with the other Spanish. From other view, it is important to highlight too, that the conquest of rights of these people in the territory of Hispanic America was not linear: after the Independence, the compulsory work of the Indians had returned in some countries. ${ }^{8}$

At the Courts of Lisbon, as consecrated in historiography, the dispatch of many projects about the Indians question, even the famous plan of civilization written by José Bonifácio, did not resulted in an extensive debate with effective decisions. On the contrary, only one of these plans, dispatched from Pará by the Colonel Francisco José Ricardo Zany - who we will talk about later - managed to pass the first barrier of the discussions: it was approved by the Comissão de Ultramar das Cortes Gerais de Lisboa, reaching to the point of being transcribed in the Diários do Congresso with a friendly opinion by the Comissão. Still, there is no register that the same project made by Zany had resulted in concrete decisions or that the very project had been discussed in plenary after its presentation by the Comissão de Ultramar and the order of impression. ${ }^{10}$ In the very Portuguese constitution of 1822 there is only one unique mention about the Indians, precisely in the last article which establish a vague obligation by the Executive and the Courts in the attempt to promote the civilization of the Indians, incorporated to a series of actions categorized as charity institutions."

Yet in the constituent debates of the Empire of Brazil, Fernanda Sposito presented that the Indians were cited since the discussions to define who the Brazilians were. In this occasion prevailed the understanding that those who were outside the living together of the "civilized" should not be considered members of the political pact. Regardless the deci- 
SPOSITO, Fernanda. Nem cidadãos, nem brasileiros. Op. Cit., p.73-74.

13

CUNHA, Manuela Carneiro da. Op. Cit., p.9-11.

SAMPAIO, Patrícia Maria de Melo. Política Indigenista no Brasil Imperial. Op. Cit.

sion of excluding the Indians who were at the forests - and the complete uncertainty about those who lived between the white men but still were identified as Indians, or those who would be incorporated afterwards - it becomes clear that this was an unavoidable problem for the Constituents. The constitutional project consecrated to the theme a single article, very similar to what had been approved at the Courts of Lisbon, with a vague promise of the government dealing with the catechism of the Indians. However, as pointed by Sposito, the Constituent Assembly sanctioned favorable measure to the project made by José Bonifácio which was also presented at Lisbon. The authoress supposes that the non-instant welcoming of the proposition was connected to a stratagem of the Constituents: the responsible committee ordered to spread copies of the project to all the Empire and to question the provincial authorities about a way to implement it at each part of the territory. ${ }^{12}$

The non-definition of an Indigenist policy in the Constituent draws as much attention as the decision to question the local governments about the matter, rather than claim the responsibility to them. It is precisely to this matter, the role of the provinces attempting to define an Indigenist policy in the Empire of Brazil, that this article intents to claim attention.

In the already cited text, Manuela da Cunha, in a superficial way, said that the provinces even legislated about the theme in their own accord, giving space to understand that it was a casual policy and resulted from the lack of definitions by the Court. ${ }^{13}$ Unlike the conclusion made by Cunha, the Indians still were a central question for the politics in many regions of the Empire and the role of the provinces in the regulation of this matter doesn't seem to be casual or secondary. Instead, seems clear that there was a clash about who would have the primacy about this matter: the central government or the provinces? As highlighted by Patricia Sampaio even during the approval of the "Rule of Missions" the discussion about who should legislate on the matter was a stress point. Sampaio demonstrate that even at the Council of State the project about the Rule of Missions suffered resistance from people like the Marquis of Paraná, who the establishment of a general rule for all the Empire would be ill because it would remove the role of the provinces to discuss the matter. More than that: it is very significant that the Marquis of Paraná in his protest against the law had set it as "misuse" of the right that was competent to the Provincial Assemblies, that on its own show that to him the natural would be the non-existence of a general law about the theme. ${ }^{14}$

This tension between the establishment of a general policy and the interest of the provinces is permanent. Even the first effort of the Parliament to create a general plan for the Indians had as strategy to consult the provinces. This is a matter that claims attention twice: first because it repeats the same procedure of the Constitutional Assembly; second because this was an absolutely unusual procedure on the practice of this power. Sent in the very first year of operation of the Chamber and the Senate, in 1826, the answers seem to explain the stalemates behind this problem: the reality of the Indian question varied considerably between the provinces. Analyzing the answers sent, John Monteiro shows that in Goiás and São Paulo, for example, they had the expectation of integration of these people, to the point of thinking that with this last answer the utilization of this manpower could be relevant to the end of the slave trade. On the other hand, the feedback that came from Paraiba did not saved words to 
17

DOLHNIKOFF, Miriam. O Pacto Imperial: origens do federalismo no Brasil. São Paulo: Editora Globo, 2005.

18

SPOSITO, Fernanda. Liberdade para os índios no Império do Brasil. A revogação das guerras justas em 1831. Almanack, Guarulhos, n. 01, nov. 2010. Available at: <http://www.almanack.unifesp.br/ index.php/almanack/article/view/715 $>$. Accessed in: March 11, 2013; SPOSITO, Fernanda. Nem cidadãos, nem brasileiros. Op. Cit. tell that every effort of catechism was made in vain, specially noting that it was impossible to entrust public offices to the Indians as intended since Pombal. But in Ceará and Pernambuco, the center of concerns was the danger of being represented by these men who, according to the provincial authorities, had gained power after the Constitutionalist Act. Moreover, it's remarkable the absence of any response by the provinces where the Indians were the center of the problems, following the example of Grão-Pará. ${ }^{15}$ Furthermore, the different levels of incorporation of these people to the world of the white men not only were different for each group, but also had different significance between the provinces. In the decade of 1840, for example, the Rio Grande do Norte claimed that it could not execute the Rule of Missions because the Indians already lived between the white men under the administration of civil authorities. ${ }^{16}$ Certainly it was a different Indian than those imagined by the writers of the Rule of Missions, but also it draws attention to the fact that the incorporation to the world of white men did not make this people lose their distinct trait to the province authorities. They still were Indians.

Given the urgency at many places, the provinces used existing mechanisms in an attempt to regulate the Indian question, in an illustration of the spaces of autonomy that existed for the local powers of the Empire of Brazil, as supported by Miriam Dolhnikoff. ${ }^{17}$ Fernanda Sposito, focusing specially in the case of São Paulo, demonstrates it very well: there was not a "legislative void" until 1845 because the provinces, with many restrictions, mistakes and success, tried their own policies or suggesting changes for the central government. In São Paulo, for example, they tried to form a specific organization to create laws concerning the Indians to be made effective, the Sociedade de Catequese e Civilização in 1830. Yet, the most emblematic example seems to be the initiative of the Conselho Geral da Província de São Paulo to require for the Parliament to abolish the just war act ordained by $\mathrm{D}$. João $\mathrm{VI}$ in 1808, a request that was answered because of such local plea. ${ }^{18}$ Sposito maps the paths that led to the revocation of these just wars, showing that the initiative of the Conselho Geral da Província de São Paulo, which would culminate into a legal and effective change, was motivated by many debates that, in turn, were powered by events in many parts of the São Paulo territory.

Obviously these local actions about the Indigenist Policy had limitations and the absence of a general law carried stalemates that created reasons for complaints, including some that were made by the members of Conselho Geral de São Paulo. However, what we want to highlight here is that the Indigenist policy and the definition of laws about this theme were not abandoned by the provinces, something that is forgotten when the sight is focused only into the legal marks determined by the Parliament The debates and the proposition of laws, even when they not resulted into effective policies, show us an important role of the legal institutions and help us comprehend the dead ends in specific regions of the Empire.

Following this thinking, this article intends to emphasize the action of the Conselho Geral da Província do Grão-Pará in the attempt to establish an Indigenist policy in the period between 1829 and 1831. In previous researches, from Reading the Annals of Parliament and sparse documents, in other works was possible to deduce that this debate was present in the discussions of the General Council of the Pará province, including at least one representation made by the Province reaching to the inquiry of the 

Edições do Senado Federal, 2004; ALENCASTRO, Luis Felipe de. 0 Trato dos Viventes: formação do Brasil no Atlântico Sul. São Paulo: Cia das Letras, 2000. p.142-143.

21

DOMINGUES, Angela. Quando os índios eram vassalos: colonização e relações de poder no norte do Brasil na segunda metade do século XVIII. Lisboa: Comissão Nacional para as comemorações dos descobrimentos portugueses, 2000. p.37-41. deputies and senators. ${ }^{19}$ Yet, confined to the Annals of Parliament it was not possible to exactly know the recurrence of this matter in the Council and its importance in the entirety of debates. At the same time, it drew attention to the fact that, despite the importance of the theme and its discussion in the General Council it failed to formulate in this organ a wide Indian policy that were implemented. This pretense - at least on what concerns the discipline and manpower of those who already lived between the white men - would only be achieved years later, at the Province Assembly with the creation of the law of the Corpo de Trabalhadores in 1838. Why such a thing happened?

In this very article is expected to answer these questions adding up to the research a group of fonts that are being gathered since 2008 in the Arquivo Público do Pará, in the Biblioteca Nacional, in the Arquivo Nacional and the Arquivo da Câmara dos Deputados. Even if it still has flaws, these documents allow us to comprehend from aspects of the elections for the General Council until details of their meetings. Emphasize here the analysis of the minutes of the Conselho Geral da Província do Pará, between 1829 and 1831 , something that was only made possible after assembling a puzzle made by documents that were scattered at many archives, a completely different reality than Minas Gerais or São Paulo, where this minutes had been published. Even if the form of construction of the minutes of these Council impose some limits to our comprehension of the debate, as it will be explained soon, without a doubt it is the best documentation to understand who were these counselors, what were the projects presented related to the Indians, which were the positions assumed and the difficulties about getting an agreement to establish a complete policy. The chronological cut covers from the beginning of the works made by the Council, in 1829, going to 1831. In this year the President of the Province is deposed, with great repercussion into the works of the General Council, including the relations of the propositions about the Indians. Also, after 1831 it begins to arrive at the Province news that in the past year, as a consequence of an action made by the General Council, the Parliament had approved a law that ended the Milícia de Ligeiros, which was the main form of recruiting Indians for compulsory labors in Pará.

The importance in Grão-Pará of the definition of an Indigenist policy In Grão-Pará of the nineteenth there was not a way to undervalue the problem of the Indians and, as we see bellow, the definition of a policy concerning these people became more and more urgent. There were many reasons to this. First it was a very expressive contingent of the population of the villages, towns and the city of Belém. In fact, almost the totality of the villages and towns that existed in Pará in the nineteenth had been created during the government of Pombal from the Jesuit Missions or some other Order that previously existed. ${ }^{20}$ So, a good portion of the people of Para were composed by descendants of those Indians that were reduced by the Jesuits and, after Pombal, became to be known as subjects of the king of Portugal, without any distinction as it was liked to be emphasized in the period. ${ }^{21}$ Therefore it was a case similar to what has already been reported in Rio Grande do Norte: even if the Indians that lived in the forest were an important matter in Pará, mainly because of the wish to resume the slave raids, the core of the question was about individuals who had their relatives living with dozens of different ethnic groups in the same space 
PORRO, Antonio. História indigena do alto e médio amazonas. Séculos XVI e XVIII. In: CUNHA, Manuela Carneiro da. História dos Índios no Brasil. São Paulo: Cia das letras, 1992.

23

SILVA, Ignácio Accioli de Cerqueira e.

Corografia Paraense ou descrição física, histórica e política da província do Grão-Pará. Salvador: Typografia do Diário, 1833; BAENA, Antonio Ladislau Monteiro. Representação ao Conselho Geral da Província do Pará sobre a especial necessidade de um novo regulamento promotor da civilização dos índios da mesma província. Anais da Biblioteca e Arquivo Público do Pará. Tomo II. Belém: Imprensa Oficial, 1902.

24

FREIRE, José Ribamar Bessa. Rio Babel: a história das línguas na Amazônia. Rio de Janeiro: EDERJ, 2004. p.181.

25

VERÍSSIMO, José. As populações indígenas e mestiças da Amazônia, sua linguagem, suas crenças e costumes. Revista do Instituto Histórico e Geográfico Brasileiro, Rio de Janeiro, n.50, tomo 1, p.295-390, 1887. It is needed to highlight that Verissimo saw the taupio as a specific population from Pará, but relied in one question, above everything else, racial and not historic. The great diffusion of the word nowadays is because, mainly the book of MOREIRA NETO, Carlos de Araujo. Op. Cit. For a critical view of the using of the word tapuio, see among others LIMA, Leandro Mahalem de. Rios Vermelhos: perspectivas e posições de sujeito em torno da noção de cabano na Amazônia em meados do 1835. Thesis (Master's Degree in History). 2008. 288 fls. Faculdade de Filosofia, Letras e Ciências Humanas, Universidade de São Paulo, São Paulo, 2008. In a recent work, Mark Harris has pointed too what he considers to be the limits of the usage of the word tapuio, even if highlighting that it was of common use in the documents of the period. For Harris, the distinctions in this territory in the Nineteenth century were not marked by the fixation of the races, for the surprising of the travelers that saw the classifications as white and Indians to be used with very fluid criteria and that depended of the very social condition of the individuals. In this sense, for example, he points that an Indian with proprieties and powers could be seen by his similar as a white man. However I believe this fluidity pointed by Harris, even if true in many situations find its limits precisely in the laws that organized the work. In the read documents, some of them noted forward, the racial distinction and especially the identification as Indian is a crucial element. On the other hand it is important to highlight that for Harris the ethnical distinctions of the Indians that lived among the white men could be an important element until the end of the Eighteenth Century, but is no longer during the Nineteenth. Among other thing, remembers an episode of Spix and Martius in the region of the Tapajós wherein when asking the Indian about his origin tribe this could not answer. See HARRIS, Mark. Rebellion on the Amazon: the Cabanagem, Race, and popular culture in the North of Brazil, 1798-1840. New York: Cambridge University Press, 2010. p.40-49. for decades and, after Pombal, not only living with the white men but also having their miscegenation encouraged. ${ }^{22}$

In the nineteenth, it was recurrent to call these people tapuios, a word also used by them to refer to themselves, as it was shown in some documents. In documents of the period there are denominations as "indios avilados" or "christian Indians" what, in general, refer to the same identify logic. ${ }^{23}$ Bessa Freire has pointed that the level of language proficiency of Portuguese or the general language also determined different ways of naming these individuals, as meek Indians, tapuios or civilized Indians. ${ }^{24}$ In the records of the period that were investigated, the pure and simple classification of "Indians" and, furthermore, the mention of specific ethnic groups are restricted to the Indians that inhabited the forests.

There is a debate about the use of terms such as "tapuios", rethought by José Veríssimo and spread by Moreira Neto, it does not simplify a multifold reality or ignore the capability of the Indians of reformulating their own identities, even in the midst of a process that pretend to thwart their ethnic identities. ${ }^{25}$ Despite recognizing that this is a relevant debate, this is not the point of this article. On the contrary, what matters here is to highlight the persistence of terms that were used to identify these people as Indians, even if some had great levels of incorporation to the culture of the white men. As it is known by the historiography and by documental records, since Pombal there were tapuios performing relevant political roles such as councilman and assuming different positions in the troops progressively, even as officers. ${ }^{26}$ In the lists of culprits from the Cabanagem, men identified with the term tapuio appear with the most divergent occupations, even as merchants. ${ }^{27}$ Once more, we insist that what is important here is to highlight that, even in such situations, these men still had their Indian identity marked as a distinct trace from the rest of the population.

What explains this persistence? Maria Regina Celestino de Almeida, analyzing the villages in Rio de Janeiro until the nineteenth century, makes a rich demonstration of how the Indians from these places have been reformulating their own identities since the sixteenth. Despite the differences in context, that analysis is significant to this discussion, because it is also composed by Indians who interact with white men and share the same space with different ethnic groups since long ago. Almeida emphasizes that the reformulation of their identities no longer have the way to save strict correspondence with the specific ethnic origins of each group, but the condition of Indian is claimed by the very individuals. Among other reasons, the Indian origin was a way to secure collective rights of these people, especially the land. ${ }^{28}$

In the tricky debate about the identity of the "indios avilados" of Pará in the nineteenth, this is a question that must be thought about and investigated. On the other side, it seems undeniable that the permanence of this distinctive trait, so marked in the relationship of these individuals with the State, was linked to questions about the control of their manpower. This because although was said that the Indians after Pombal were subjects to the king of Portugal without any distinction, in fact it was applied to these men the so called provisions against the idleness: in general, right after the affirmation of the liberty of the Indians during the Pombal Government, the Directory disciplined this manpower. The Indians now inhabitants of the villages and towns of the Captaincy could practice relevant public roles, had their marriage with white men encouraged, but 
MACHADO, André Roberto de A. A quebra da mola real das sociedades: a crise política do Antigo Regime Português na Província do Grão-Pará (1821-25). São Paulo: Hucitec : FAPESP, 2010; CLEARY, David. Lost Altogether to the Civilised World: race and Cabanagem in Northern Brazil, 1750-1850. Comparative Studies in Society and History, 1998. NOGUEIRA, Shirley M. S. "A soldadesca desenfreada": politização militar no Grão-Pará na Era da Independência (1790-1850). Dissertation (Doctorate in History). 2009. 341 fls. Universidade Federal da Bahia, Salvador, 2009. In fact, Pombal cared to create a kind of Indian elite, distributing a number of privileges especially to the leaders of these people, named Principais. About his, see among others SAMPAIO, Patrícia Maria de Melo. Espelhos Partidos: etnia, legislação e desigualdade na colônia, Sertões do Pará, 1755-1823. Dissertation (Doctorate in History). 2001. 331 fls. Universidade Federal Fluminense, Niterói, 2001; DOMINGUES, Angela. Op. Cit.; ROCHA, Rafael Ale. Os Oficiais índios na Amazônia Pombalina: Sociedade, Hierarquia e Resistência (1751-1798). Dissertação (Mestrado em História). 146 fls. Universidade Federal Fluminense, Niterói, 2009.

27

Document from Instituto Histórico e Geográfico Brasileiro. Rio de Janeiro, Brasil. lata 290, pasta 3.

28

ALMEIDA, Maria Regina Celestino de

Metamorfoses indígenas: identidade e cultura nas aldeias coloniais do Rio de Janeiro. Rio de Janeiro: Arquivo Nacional, 2001

29

Diretório que se deve observar nas povoações dos indios do Pará e Maranhão enquanto sua majestade não mandar o contrário. Lisboa: Oficina de Miguel Rodrigues, 1758. IN: MOREIRA NETO, Carlos de Araújo. Índios da Amazônia: de maioria a minoria (1750-1850). Petrópolis: Vozes, 1988. About the Directory see SAMPAIO, Patricia Maria de Melo. Espelhos Partidos. Op. Cit.; DOMINGUES, Angela. Op. Cit.; COELHO, Mauro Cezar. Do sertão para o mar - um estudo sobre a experiência portuguesa na América, a partir da colônia: o caso do diretório dos indios (1751-1798). Dissertation (Doctorate in History). 2006, 433 fls. Universidade de São Paulo, São Paulo, 2006.

30

About the entrance of the African slaves in Para see BEZERRA NETO, José Maia. Escravidão Negra no Grão Pará (séculos XVIII-XIX). Belém: Pakatatu, s.d; SALLES, Vicente. O Negro no Pará, sob o Regime da Escravidão. Belém: UFPA, 1971; DIAS, Manuel Nunes. A Companhia Geral do Grão-Pará e Maranhão (1755-1778). São Paulo: Coleção da Revista de História, 1971. For a comparision between the impact of the Pombal's reforms and the entrance of African slaves see MACHADO, André Roberto de A. A quebra da mola real das sociedades. Op. Cit.

31

About the law of 1798, look for SAMPAIO, Patricia Maria de Melo. Espelhos Partidos. Op. Cit. Em um artigo, Patricia Sampaio even stats that the law of passed to tolerate that entrance not exclusively of Indians, but also blacks and whites at the Milicia de Ligeiros that could not still remained under tutelage of directors who had among their mainly attributions to ensure the division of this Manpower between the private, ensuring at the same time the salaried employment of these men. ${ }^{29} \mathrm{We}$ see that even with the intentions of Pombal to make the African slaves the main group of laborers in the State of Grão-Pará and Maranhão, ensuring the offering of Amerindians manpower in the region still had been central for the Empire of Portugal in this part of America.

This would be of great importance because if it is undeniable that Pombal brought African slaves to Grão-Pará in such great numbers than had been until then, it is also true that in this Captaincy the reforms from the middle of the Eighteenth did not had the same success as they had in Maranhão. For as much as in the last the success of the agricultural initiatives encouraged by the Monopolist Company, mainly cotton, secured the increase in wealth and the continuous entry of African slaves, in Pará this increment did not reversed the profile of the local manpower: the importance of the African slaves had rose sharply, but the main laborers of the territory of Pará were still Indians, especially those who lived between the white men and could be distributed by the authorities. ${ }^{30}$

Following this train of thought it is of great importance that the understanding of the legislation of 1798 that put an end to the Directory in Pará also had emerged from the supposedly natural tendency of these men for idleness to create laws that forced them to compulsory labor on public and private works. In other words, even after the changes caused by the law of 1798 related to the Directory, the logic that assured the access to this enormous manpower remained. All these Indians started to be listed by military officers and submitted to the organization of the so called Milicias de Ligeiros, the main apparatus for recruitment for the compulsory labor of the tapuios. By the law, any of these individuals that had no means to prove a fixed occupation could be recruited to take part in public or private works. We highlight that even if they were paid for the work - though, sometimes, with years of delay for the payment - it was not given to them the opportunity to refuse to fulfill the demanded tasks. ${ }^{31}$

Although they kept the access to this manpower, the law of 1798 had created restrictions that, as we will see in the text, always appeared as tension points regarding those who wanted more freedom in the recruitment of the Indian laborers. Not by chance, propositions to end the restrictions created by the law of 1798 appear, frequently, as central points in the changes that were intended to be implemented through the projects of Indigenist policies formulated in the province. One of these restrictions is the prohibition of the old slave raids of Indians from the forest, even if the law assured that, under the authorization of the orphan judges, the residents could, by many years, keep as salaried workers in their proprieties Indians that supposedly had left their tribes of their own volition to live with the white men. ${ }^{32}$ Other point of continuous conflicts after 1798 is regarded to the end of the tutelage of Indians, a power that in the previous law was exerted by the old Directors. Since very soon and with great recurrence during the Nineteenth, part of the males of the province were assigned by the authorities and by owners for this purpose, under the point that the end of the tutelage had permitted the emptying of the villages because of the continuous abandon by the tapuios. To have an idea about the tension around the right of free transit of these Indians it is exemplar an episode written by Patricia Sampaio: in the village of Meglaço, in 1799, 
prove a stable work. However, in every document read until today by this scholar referring to the Nineteenth there are no evidences of the participation of other groups in the Milicias de Ligeiros that were not Indians. About this see SAMPAIO, Patrícia Maria de Melo. Vossa Excelência mandará o que for servido"...: politicas indigenas e indigenistas na Amazônia Portuguesa do final do século XVIII. Revista Tempo, Niterói, n.23, 2007. About the law of 1798 , look for MACHADO, André Roberto de A. A quebra da mola real das sociedades. Op. Cit. too.

32

The understanding by Maria Regina Celestino de Almeida is that this gap permitted, indeed, private slave raids, supposing that this served the privates much more. The truth is that the law was very critical to the slave raids and this gap seem not be able to end with the obstacles for the obtainment of Indian manpower, given the recurrence that is requested the return of the raids. ALMEIDA, Maria Regina Celestino de. Os índios na história do Brasil. Rio de Janeiro: FGV, 2010. p.141-150. However, it is necessary to acknowledge that even today it is not possible to calculate the number of Indians that were inside the properties in this condition or that were simply enslaved during the Nineteenth century. 33

SAMPAI0, Patrícia Maria de Melo. Vossa Excelência mandará o que for servido". 0p. Cit., p.48 e p.53.

34

SPIX, Johann Baptist von; MARTIUS, Carl Friedrich Philipp. Viagem pelo Brasil: 1817-1820. Belo Horizonte / São Paulo: Itatiaia : Edusp, 1981; SILVA, Ignácio Accioli de Cerqueira e. 0p. Cit.

35

Arquivo Nacional. Rio de Janeiro, Brasil. IJJ9 - 108 - Ministério do Reino e Império. Pará, Correspondência do Presidente da Província (1829-31), doc. 313.

36

For Raquel Santos the crescent insubordination of the tapuios was also because of the fact that these had acquired knowledge, even if partial, about the debates in Cádiz referring to the Indians. SANTOS, Raquel Dani Sobral. Op. Cit.

37

Arquivo Histórico Ultramarino. Lisboa, Portugal. ACL, CU 013, Caixa 155, doc. 11.875 (Projeto

Resgate). Edição n. 01, de 22 de maio de 1822.

Sobre 0 Paraense, a melhor análise é de COELHO,

Geraldo Mártires. Anarquistas, Demagogos e

Dissidentes: a imprensa liberal no Pará de 1822.

Belém: CEJUP, 1993. a military officer asked the permission of the Governor to take three Indian women - two spinners and one master of the loom factory - because these had abandoned the village that in turn not intended to stay without the skilled work of these women. The attitude to treat the displacement of these Indians - it is worth mentioning that they were free people - as a crime of desertion was common to the point where the Governor have to manifest himself, even in 1799, remembering that the end of the Directory assured free transit to these individuals as to any subject of the King. ${ }^{33}$ Anyway, looks clear that the conditions of free people of the tapuios were always called into question.

At the beginning of the decade of 1820 this image still had been in its own general lines. The contemporary chronicles and the travelers' report registered the omnipresence of the Indians in almost any of the province activities. They were occupying functions reserved to the African slaves in other parts of Brazil, but were in army positions too, from the most lowranking to a high ranking. ${ }^{34}$ At the decade of 1830 , a report by Viscount of Goiania gives us an understanding of the importance of this manpower in the province. In a long text where Goiania pretended to give its own version about the coup d'état that deposed the president of the province - this episode will be explained in details later - said that in front of the increasing of the conflicts and the opposition to his administration, it were suggested to him a cunning trick to recover the order: to disseminate the fear of a riot of the African slaves, something that Goiania ironized writing that this method were the most used in the period to intimidate the people and regulate the mood. More important, however, it is the consideration for this manpower in the province, regarding the Indians:

In Pará, almost every servant people are caboclo. And if there were African slaves of any kind, not a single problem they would give me because the experience had showed me that it is in those cases that Brazilian and Portuguese hold hands and even the mulatos make union against the blacks. So from this boogey I do not fear. ${ }^{35}$

From the context of the document, the caboclo people that Goiania is referring to are the Indians that lived between the white men and that were enlisted in the Milicia de Ligeiros. The enormous dependence of this manpower caused it to be in the center of the political life of the province too. It is exactly this that is stated in the beginning of the decade of 1820, during the debates around the Vintismo and Independence.

As said previously, on the contrary to what happened at Cádiz, in the Courts of Lisbon no nominal policies intent to the Indians had been established, be those who were in contact with the Portuguese civilization, those who already lived in the villages, towns and city of Belém. Yet, the tapuios started to reclaim to themselves guarantees and rights approved at the Courts of Lisbon, in a logic that made their past condition of vassals from the King of Portugal to turn into citizenship. ${ }^{36}$ Among the questions discussed in this article, the problem that was shown in this situation is that the claim of these rights often implied in an attempt of these groups to raze the mechanisms that assured the exploration of their compulsory labor.

An example of such thing is the execution of a law approved by the Courts of Lisbon that, under the argument of pretending to encourage the agriculture, forbid the recruitment for the Militias. The law was published in May, 1822 in the first issue of the journal 0 Paraense, the first newspaper of the province, which certainly contributed to its knowing. ${ }^{37}$ 
38

Arquivo Histórico Ultramarino. Lisboa, Portugal. ACL, CU 013, Caixa 155, doc. 11.874 (Projeto Resgate), 06 de julho de 1822

39

Arquivo Público do Pará. Belém, Brasil. Códice 748, doc. 33.

40

Maybe the most remarkable example is the dismissal of the Arsenal Intendant João Martins. Ver Arquivo Histórico Ultramarino. Lisboa, Portugal. ACL, CU 013, cx. 151, docs. 11.654 e 11.644

41

For a long analysis about this conflics and the bond with the compulsory work of the tapuios, see MACHADO, André Roberto de A. A quebra da mola real das sociedades. Op. Cit.
Just under two months later, José Maria de Moura, Arms Governor of the Province wrote to Lisbon saying that he would not abide by the law. In the letter he exposed in details the situation above: he said that the majority of the population of Pará was composed by Indians and those, under the law of 1798, were subdued to the military power So, following the description made by the Arms Governor, the Indians that were not recruited to frontline troops where engaged into Militias, especially in the Milicia de Ligeiros, which was responsible to regulate the compulsory work of such individuals at all activities of the province. Despite the caution to not confront the power in Lisbon, Moura has been adamant: in his vision the enforcement of the law in Pará was impossible because the Indians would not work if they were not forced to do so as they were from the recruitment to the Milicia de Ligeiros. It is mostly here that Moura shows the stalemate about this new politic moment: according to the Governor, the Indians were refusing the recruiting, claiming for them the right created by the law of the Courts of discharge from the Militia, which placed the authorities in a dilemma. ${ }^{38}$

This was far from being the sole episode of this type. In 1823, the Judge Ordinary from the Vila Nova de El-Rei complained that he could not gather the number of militia that was required because the Indians were threatening him under the allegation that the Courts did not permitted any more arrest warrants without conviction of guilt and the practice until then was to keep these men in jail or trunks till they got to the right number of required laborers. ${ }^{39}$ Similarly, during the Vintismo and after the Independence it is possible to verify protests against civil servants responsible for the forced recruitment of tapuios, trying to link such practice as acts of despotism that the Constitutionalism has come to overthrown. ${ }^{40}$

As demonstrated in previous works, with the Independence the situation worsened. For those who wanted to keep the control of this manpower the end of the relationship with the Courts of Lisbon had put an end to the legal questions that gave base to the refusals of recruitment written above. For the tapuios, however, the rupture with Lisbon was a movement such as or even more radical than the Vintismo. Even if the war that followed the years of 1823 and 1825 in many parts of the province is complex, it seems clear that the clashes about the keeping of the compulsory work of the tapuios was a central point, particularly powered by the fact that many of these individuals were armed with weapons. ${ }^{41}$

In recent researches it became possible to show that the mechanisms of exploration of manpower from the tapuios in Para continued to be the same of the law of 1798 at least until 1831. Yet it seems undeniable that the questioning of this law during the Vintismo and the Independence weakened its legitimacy. Because of this the definition of an Indigenist policy linked with the new political system was vital in the Pará province. Certainly it is not by chance that, as we will see, that this is the theme that most deserved proposition of projects in General Council of the Province. In addition to give more legitimacy to the mechanisms of usage of these laborers, it is necessary to highlight that there were pressures in the interior of the province to modify the devices that had been determined by the law of 1798 too and those that were considered obstacles by the proprietors and public servants responsible for the recruitment. Certainly this is one of the impulses that also makes other projects intended for the Indians to be formulated in the province before and after the operation of 
42

See ZANY, Francisco José Ricardo. Projeto para os índios do Grão-Pará. IN: Diário das Cortes, 1821/1822. Sessão de 26 de Agosto de 1822. Available at: <http://debates.parlamento.pt>. Accessed in: March, 01 2014. It is not totally clear in the Diaries of the Courts if the topics of the project were originally written completely by Zany, if they were only modified by the Overseas Committee or if they were fully written by the later after the complains and suggestions sent by Zany.

43

I thank my advisee Samuel Rocha Ferreira for locating this document.

44

Arquivo Público do Pará. Belém, Brasil. Códice 855 , doc. 45 the General Council, and that invariably they try to revert the restrictions to the slave raids and the end of the tutelage, the latter identified as the responsible device from 1798 for the right of free transit of the Indians and the consequent desertion of the villages.

These two questions are in the center, for example, of the already cited project sent by Zany to the Courts of Lisbon. With the main focus the Rio Negro, Zany complained about the restrictions of the slave raids, remembering that existed in that territory few white men and very few African slaves, on the other hand there were 26 Indian nations that remained untouched under the protection of Portuguese determinations. On the other side, it exposed as well how a problem that he called absolute freedom of the Indians that made them leave their villages and lost themselves to the "catholic church, the State and the private sector". From his complaints and suggestions, the Comissão de Ultramar das Cortes de Lisboa ordered to print a project of 20 articles that included the claims made by Zany. In a train of thought very closer to the Directory, he instructs the creation of a general inspector for the Indians of the province and delegates in the villages. Regarding the forest Indians, the project not only foresaw the continuity of the slave raids, but also defined that the chosen Inspector should bear the costs of such activity. Once captured, these Indians would be divided between the privates that could employ them as laborers for six years, been the tapuios included among those who could have them. Regarding the "indios avilados", the proposed structure remembers the Directory too: it would be up to the inspectors to distribute the Indians to the various types of work and ensure their payment. More than that, according to the project the tapuios lost their free transit, not being able to leave their villages without the consent of the inspectors and delegates, these two being responsible to search for the whereabouts of the first when they were not at their original villages or at the employments that they were designed to. ${ }^{42}$

After the Independence, in 1825, again came from this region a new plan of civilization for the Indians, this time elaborated by the second lieutenant Antonio Joaquim de Bitencourt e Sá and sent to the Court. ${ }^{43}$ In general lines it is almost a repetition of the same motto that had been defended a few years ago by Zany. It begins praising the resources of the region and then gets to the point of telling that the existence of Indians at the forest prevented the exploration of all this potential because they even attacked the ships. To solve this problem Bitencourt e Sá had only one solution: resume the slave raids. In his words: "the civilization of these Indians is of great concern for the Nation it not just tends to remove the obstacles mentioned but it will increase the national wealth with such thousands arm useless tot themselves and the State".44

If there is an agrarian interest, clearly he is secondary in the proposal, because there is not only one line referring to what they would do with the lands after the removal of the Indians. On the contrary, the core of the discussion is about the Indians and more specifically in the controlling of the manpower. This way, Bitencourt e Sá asks to be the performer of this plan, compromising to finance the slave raids, something that once more remembers the plan of Zany. However, on the contrary of the previous project, the lieutenant makes clear that the raids would be realized by force, if necessary, a resort expressly banned by the Courts of Lisbon. About the fate of the Indians that lived in the villages and those who would be 
45

Arquivo Público do Pará. Belém, Brasil. Loc. Cit.

46

At least not in its original content.

47

Arquivo do Instituto Histórico e Geográfico do Pará. Belém, Brasil. Lata 415, pasta 8. Collecção das leis provinciaes do Pará promulgadas na primeira secção que teve principio no dia 2 de março e findou no dia 15 de maio de 1838 e vão numeradas de 1 a 13. Pará: Tipografia Restaurada, 1838.

48

About the Corpo de Trabalhadores see FULLER, Claudia Maria. Os Corpos de Trabalhadores: política de controle social no Grão-Pará. Revisto de Estudos Amazônicos, Belém, v.lll, n.01, p.93115, 2008; MOREIRA NETO, Carlos de Araújo. Op. Cit.; MACHADO, André Roberto de A. 0 direito e o arbitrio em tempos de Guerra: os debates no Parlamento em torno das garantias constitucionais durante a repressão à Cabanagem (1835-40). IN: NEVES, Lúcia Maria Bastos P.; BESSONE, Tânia Maria (org.). Dimensões Politicas do Império do Brasil. Rio de Janeiro: Contra Capa, 2012. incorporated Bitencourt e Sá is economic but revealing: said that in those situations it would be followed the laws of the Directory. Once more it became explicit the critic of the law of 1798.

Other important thing to realize in both projects of Zany and Bitencourt e Sá is that the themes of the slave raids have a greater feature than those that would be elaborated by the General Council of the province, far more focused in issues related to discipline and regulate the manpower of the "indios avilados". Maybe an explanation of this is just in the exposure of the Project by Bitencourt e Sá: according to him, historically the Indian slaves would not remain in their home area, they would be brought to Belém and from there distributed as expense to regions such as Rio Negro. ${ }^{45}$ As so looks like that in this question the situation in the center of province was different from the countryside, wherein the last there was the need to restore the manpower in addition to discipline it.

As we know, like the projects of an Indigenist policy developed by the General Council of the Para province where never executed ${ }^{46}$, the proposals made by Zany and Bitencourt de Sá had no success too. Yet, it would be in the range of the province that an Imperial Law would finally regulate the control of the manpower of the Indians from Pará. As the second law made at the Provincial Assembly it was created in 1838 the Corpo de Trabalhadores. In the middle of the Cabanagem, the Corpo de Trabalhadores assured that every free man from Pará that have not a known profession, excluding the white men, could be forced to work either to private works or public works ${ }^{47}$ Here we have three points to highlight: First the evidence that his was a matter of urgency in Pará to the point of being the second Law stablished by the Provincial Assembly. In the second place, the racial exception, as the White men are the only that could not be forced to work. In third place, even if not identified as an Indigenist policy, on the contrary of the Project made by Zany, Bitencourt and those elaborated at the General Council of the province that were always addressed as plans of civilization, the great impact of the act was in discipline the labor of the tapuios including for their demographic dimension, even if the law permitted the compulsory work of the black slaves and freed mestiços. In fact, now under the legitimacy of a law promulgated by the Empire, the apparatus of the Corpo de Trabalhadores resumed in wide range the organization of the Milicias de Ligeiros that, as we will see, had been extinct by the Parliament in 1831. One of the questions that reinforced such impression is that the law assured that the commanders and officers responsible for the Corpo de Trabalhadores would be the ones that exercised this function in the extinct Milicia de Ligeiros. It would be up to these individuals the distribution of the manpower to the public and private works. Other question is that the new law praised critics of the law from 1798: it was assured that the men listed in the Corpo de Trabalhadores could not leave their villages without the permission of the officers. In other words, the tapuios and the others under this regime, even if freed, no longer had the freedom of transit. ${ }^{48}$

After the reflection made above, it seems clear that the definition of an Indigenist policy in Pará was something important in the province, even raising local propositions for the theme before and after the existence of the General Council of the Province and always centered into a common aspect: the preoccupation to regulate the labor of the Indians. A partir da reflexão acima, parece evidente que a definição de uma política indigenista no Pará era algo importante na província, inclusive suscitando propos- 
49

The minutes of Pará made clear that the electoral instructions of 1824 were followed rigorously. For this instructions, see the Edict of March 26, 1824 - Orders to proceed with the election of the Deputies and Senators of the Legislative General Meeting and the members of the General Councils of Provinces. IN: SOUZA, Francisco Belisário Soares de. O Sistema Eleitoral no Império. Brasilia: Senado Federal, 1979.

50

SLEMIAN, Andréa. Sob o Império das leis: constituição e unidade nacional na formação do Brasil (1822-1834). São Paulo: Hucitec : FAPESP, 2009. p.148-159.

51

Sérgio Buarque de Holanda makes an important safeguard when showing that the automatic linking between Liberalism and the decentralizing pretension, even if consecrated in our history, was not common sense among the men of the period. HOLANDA, Sérgio Buarque de. A Herança colonial - sua desagregação. IN: ___. (org). História Geral da Civilização Brasileira. Tomo II - 0 Brasil Monárquico. Volume 1 - 0 processo de emancipação. Rio de Janeiro: Bertrand Brasil, 1997. p.15-20.

52

About the period and this reforms, see among others FLORY, Thomas. El juez de paz y el jurado en el Brasil Imperial: control social y estabilidad política en el nuevo estado. México: Fondo de Cultura Económica, 1986. cap.1; de SLEMIAN, Andréa. Op. Cit.; e de DOLHNIKOFF, Miriam. Op. Cit.

53

MACHADO, André Roberto de A. Machado. As "reformas em sentido federal". A atuação dos representantes do Grão-Pará no Parlamento e as expectativas na província em torno do Ato Adicional. Revista Estudos Amazônicos, Belém, v.4, n. 01, p.57-58, 2009. tas locais para o tema antes e depois da existência do Conselho Geral de Provincia e sempre centradas em um aspecto comum: a preocupação em regular o trabalho dos indigenas. Bellow we will see how the Council sent and expressed this local request.

The Councelors and the dynamic of the General Council of the Pará Province The institution of the General Council had been one of the most important achievements of the political groups that defended more freedom to the government of the provinces during the first years of the Empire of Brazil. The existence of this Council was expected in the Constitutional Chart of 1824 and, as we will see, it became to provide in that year the election of those offices, even in Pará, together with the choosing of deputies and senators and members of the Presidential Council. ${ }^{49}$

Yet, the operation of this institution only began after 1828 since it depended from a regulation of the Parliament that took two years of intense clashes between the Senate and the Chamber about the details of the Project. In this sense, it is exemplary that at the final stage of the negotiations the regulation had stopped between the desire of the Chamber to give the counselors the immunity to make critical issues and the solid decision of the Senate not to accept such formulation. This debate, somehow, synthesized the positions between those who desired to increase counselors' powers front to other provincial authorities, such as the president and those who rejected that referral. Andréa Slemian shows that the urgency of the majority of the deputies to make work the General Councils of the provinces was crucial for the Chamber to leave the clashing against the Senate and temporarily give up about the immunity of the counselors. ${ }^{50}$

It was not by mere chance that the majority of the deputies accepted the retreat. The creation of the General Councils of the Province was an important segment for the action of the political group that was consecrated in the historiography as "liberals" and identifying them as the protagonists of the efforts to decentralize the political and administrative decisions of the Empire. ${ }^{51}$ In less than a decade of the beginning of the legislative works, in 1826, are created institutions pointed towards this new direction such as the Judges of Peace, the National Guard and posteriorly the very Provincial Assemblies that would substitute the General Councils after the constitutional reform..$^{52}$ Particularly, the creation of the General Councils was urgent in the context that initiated the political life of the Empire, when the provinces had few mechanisms to refer and to manage their requests. The high grade of centralization of the decisions becomes clear at the minutes of the Parliament. During the first parliament term, between 1826 and 1829, many deputies devoted their mandates to make requests restricted to the everyday of their own provinces, such as the simple request to make a contract for a teacher to a school located in the countryside, the construction of a road, a bridge or even the request for ground to build a Seminar. It was precisely a deputy from Pará, named João Cândido de Deus e Silva, which is maybe the most perfect example of such profile: in his first two months of mandate he formalized twenty-five projects of such type. ${ }^{53}$. Obviously, demands of such nature that frequently were presented directly to the plenary without having to go through any commission that fell into abyss. As said countless times, especially at the Chamber there was no condition for the parliamentarians to begin a discussion about the requests that were little known and that were 
54

SLEMIAN, Andréa. Op. Cit., p.145-200; DOLHNIKOFF, Miriam. Op. Cit., p.59-60.

55

Law of August 27, 1828. Gives regiment for the General Councils of Province. IN: Coleção das Leis do Império do Brasil. 1828, parte primeira. Rio de Janeiro: Tipografia Nacional, 1879. p.10-23.

56

ANAIS do Parlamento Brasileiro. Câmara dos sr. deputados, em 4 de junho de 1833. Available at: $<$ http://imagem.camara.gov.br/pesquisa_diario_ basica.asp>. Accessed in: March, 012014.

57

ANAIS do Senado do Império do Brasil. Em 11 e 27 de outubro de 1830. Available at: <http:// www.senado.gov.br/publicacoes/anais/asp/IP AnaisImperio.asp>. Accessed in: March, 012014. The law aproved determined that the Foreigner had a deadline to present themselves before the Judge of Peace and register their presence in the province. The same way, to retire from the Province they also needed an authorization.

\section{8}

ANAIS do Senado do Império do Brasil. Em 23 de maio de 1832. positioned, in general, without taking into account the funding sources to execute them.

With its creation at 1828, the General Council could suggest political measures of specific interest to their provinces, but the transformation of such proposition into law still was conditioned by its approval at the Parliament. It is necessary to emphasize that this political body did not have any tax authority too, being the provincial budgets still conditioned by Deputies and Senators. ${ }^{54}$ Despise these limits the General Council seemed a great change, because the requests of the province would be referred after a local debate and the obtainment of minimal agreement capable to approve it in this forum. After reading the regulation of the General Council and even the minutes of this institution at Pará it becomes clear that its operation was thought so it would largely replicate the Parliament, with a series of rites that pretended to mark its own dignity and power ${ }^{55}$ As it had a throne speech in the beginning of the legislative works at the Court, in the province the President too directed communications to the General Council, pointing priorities that claimed his attention. And as at the Parliament, the counselors directed a response that in some occasions could express disagreements or censorships to the Executive Branch. The organization of the works, debates and voting, in addition to the complete Independence of management regarding the Executive Branch, everything remembered the work of the Deputies and Senators.

Despite the enthusiasm born from the creation of the General Council, soon they realized its limitations. As said before, even after being approved in the voting, the proposal of the counselors had to be sent to the Parliament and only if confirmed in this last instance it would have any practical value. As we can imagine, this was a long and hard road, since the proposals had beginning to come in dozens, from all provinces. To have an idea, in the middle of 1833 there already were counted more than 200 proposals that came from the Province Councils that still awaited comment of the Parliament, some of those still were in the drawers of the Chamber and Senate over four years. ${ }^{56}$ Once more, the case of Pará is exemplar: until 1834 when the Constitutional reform extinguished the General Councils in favor of the Province Assemblies, only one proposition managed to go through the Chamber and the Senate and in the end be approved and became law. ${ }^{57}$

Front to the impossibility to answer the requests of the provinces, they made various reform proposals. In 1832, for example, the senator José de Alencar suggested that the propositions made by the General Council that could get an approval rate of two-thirds from their Counselors would be automatically valid, plus the same percentage of the members from the Presidential Council and a sanction from the very president. Although being a process difficult as well, the proposal has been considered absurd by the Viscount of Cairu who claimed that the Central Government would be blind. This made clear the open resistance from part of the Parliament to give up the absolute control of the final decision about the requests of the province. ${ }^{58}$

As result, logically, the frustrations increased. Realizing that a resolution send by the General Council of Maranhão, rather than being approved had its reading delayed until the arrival of various information demanded by the Senate, the Viscount of Alcantara, a Senator from that State, manifested himself severely: with no mince words, he said that the projects sent 
LEME, Marisa Saenz. Dinâmicas centripetas e centrifugas na formação do Estado monárquico no Brasil: o papel do Conselho Geral da Província de São Paulo. Revista Brasileira de História, São Paulo, v.28, n.55, jun 2008.

61

ANAIS do Parlamento Brasileiro. Em 25 de abril de 1829 .

62

ANAIS do Parlamento Brasileiro. Loc. Cit.

63

LEME, Marisa Saenz. Op. Cit.
64

Edict of March 24, 1824 - Orders to proceed with the election of the Deputies and Senators of the Legislative General Meeting and the members of the General Councils of Provinces. IN: SOUZA, Francisco Belisário Soares de. O Sistema Eleitoral no Império. Brasilia: Senado Federal, 1979. were treated differently according to the province that they originated, to the point of claiming that already had seen true absurdities. Two weeks later he was clearer: to him the provinces of the north were being harmed by that game. ${ }^{59}$

Regarding some provinces having privileges or not during the processing of their proposals, the fact is that despite the rule for the creation of these Councils being uniform for all the Empire, there were differences between them that affected directly their prestige, influence and even the nature of their proposals. The first who draws much attention is that the proximity of the Council regarding the Court could be decisive to its composition or to improve its reception between the deputies and senators. In São Paulo, as example, one of the most active counselors was Father Feijó, who at the same time was one of the top parliamentarians of the period. ${ }^{60}$ Meanwhile, Bernardo Pereira de Vasconcelos not only had his influences inside the chamber but was also engaged in matters and positions in Minas Gerais. The consequence of this was his proximity with themes discussed in the General Council of his province, something that even earned him the unbiased defense to propositions made front to the critics made by Parliamentarians. ${ }^{61}$ This was possible in some places near the Court, such as São Paulo or Minas Gerais, because the period of the reunion of the General Councils, between November's end and the January, was done during the recess of the Parliamentarian term. On the contrary, the long time wasted to travel between the Court and Belém itself prevented the participation as a Counselor to any representative of Pará or even to monitor closely the developed discussions. Consequently, in the analyzed meetings, the Counselors were all prominent figures of the local policy, but none arrived in the Court stage. Similarly, was not among the Counselors the Bishop Romualdo Coelho, a man that still had great influence or holders of the presidency of the province during the Empire, such as Araújo Rozo inhabitant of Pará, who was still active.

Maybe the absence of politicians with more transit inside the Court had eased the focus of the Council to be tied with the province if compared to the situations of Minas Gerais or São Paulo. Between the proposals that came from Minas Gerais, for example, the first of them lectured about the necessity to delay the deadline for the slave trade, a matter clearly out of the discussion of the General Councils. ${ }^{62}$ As for São Paulo, Marisa Leme shows that there was a continuous attempt to intervene in matters of national poli$c y$, with pronouncements about general questions and actions of the parties inside the Court. ${ }^{63}$ Differently there was a caution from the Pará Counselors to focus at local questions, only reporting to the national policy in specific matters, generally linked to provincial subjects.

For the General Councils of more populated provinces such as Pará, there should be elected 21 Counselors. The elections to the Council happened simultaneously with the elections to Deputies and Senators and with the same procedures, obeying this order and producing to the voter a list with each one of the roles. Pará was divided into 10 electoral zones: the city of Belém and the towns of Bragança, Viçosa, Santarém, Barcelos, Marajó, Nova da Rainha, Crato, Olivença and Cametá. Each one of these zones should send their lists with the voted names for Counselors to the Chamber of Belém, where the last sum of the votes and the indication of the chosen were finally made. ${ }^{64}$

After the research in many archives it was possible to find a piece of 
65

Arquivo Nacional. Rio de Janeiro, Brasil. IJJ5 - 18. Ministério do Império. Eleições. Pará. Correspondências (1824-49). Both in 1824 as 1828 , the headquarters of the electoral zones were slightly different than those established in the decree of 1824

66

About this, see MACHADO, André Roberto de A. A quebra da mola real das sociedades. Op. Cit., cap. 4 e 5.

67

About the comparision between this elections, see MACHADO, André Roberto de A. Redesenhando caminhos: o papel dos representantes do Grão-Pará na primeira legislatura do Império do Brasil (1826-29). Almanack Braziliense, São Paulo, v.10, p.75-97, 2009; MACHADO, André Roberto de A. 0 Fiel da Balança. Op. Cit.

68

Arquivo Nacional. Rio de Janeiro, Brasil. IJJ5

- 18. Ministério do Império. Eleições. Pará.

Correspondências (1824-49). those lists of the electoral zones from Pará in the National Archives, both for the years of 1824 and 1828. Sadly, for example, it was not possible to locate the general minute with the total votes of the Counselors, which would permit us to know who the most voted were. The minutes between 1829 and 1831 only identify those who took by the time they joined the Council, which was possible to fix 20 names, including the surrogates that exercised the role. It is also to be regretted the absence of such lists of important places, like Belém. The amount of information at the lists varies widely, with some describing only the names and the votes while others add the occupations and the residence locations. Even if relying only on partial data it is possible to take some important notes, such as the differences about the profiles of the voted in 1824 - that did not took office because of the lack of regulation of the Councils - and the counselors chosen in 1828 that will be the characters of this article.

From 1824 were located five electoral minutes: from the villages of Vigia, Cametá, Santarém, Macapá and Marajó. ${ }^{65}$ Considering the 21 most voted names from each list the first thing that draws attention is the great number of military officers that were elected, some of them are officials from the Milicia de Ligeiros. They are 14 officers identified in Vigia, 13 in Cametá, 13 in Santarém, 13 in Macapá and surprising 16 in Marajó. Meanwhile the quantity of people with other occupations such as bachelors in Law or from the clergy is low on the contrary to what would be in 1828. Moreover, the reflex between the two elections is very different. This is expressed by the low number of voted in 1824 that match to the elected Counselors in 1828. At Vigia, Santarém and Marajó they are only two in each list, at Cametá one and at Macapá none. It also draws attention the fact that it was not mentioned not even a single time characters that would be central in the General Council now studied, such as Batista Campos, by the time a main character in the provincial policy. There are some explanations to this: first, the province lived in 1824 a civil war that certainly contributed to the leading figure of the military. ${ }^{66}$ Directly linked to that, the election for the General Council of the Province seemed to follow the same tendency that I described for the elections of deputies in Pará: In 1824, in the middle of the repression of the civil war, the chosen names had a more conservative character. In 1828 the names chosen for the Parliament are identified more as a liberal stance. ${ }^{67}$ Apparently this change in character is not so radical in the General Council, but without a doubt it is more plural than during the first election. Other important point to highlight is the great dispersion of the votes: of the 105 names that composed the 21 most voted from each list, around 28 are cited only at one electoral zone. On the contrary, only three names succeed in appear on four different electoral zones. We believe that this is enough to show the nonexistence of a closed list containing names to be voted and that if there were attempts of the provincial powers to control the plea, the result was fruitless. Other point to highlight is that it doesn't look like the dispersion of the votes shows the powerful local members because when the list informs the place of residence, it is often distinct from the electoral zones. ${ }^{68}$

These last aspects are repeated in the elections of 1828. From this plea were located minutes from four electoral zones: Cametá, Porto de Moz, Macapá and Rio Negro. Of the 84 indicated names, 40 are also cited at only one electoral zone. However, only three names appear on three of the four lists. Even if at Macapá and Rio Negro the names identified as 
69

Arquivo Nacional. Rio de Janeiro, Brasil. Loc. Cit.

70

MACHADO, André Roberto de A. 0 Fiel da Balança. Op. Cit.

71

Arquivo Público do Pará. Belém, Brasil. Códice 889, Atas do Conselho Geral de Província, em 29 de novembro, 1 e 14 de dezembro de 1830.

72

NOGUEIRA, Shirley M. S. "A soldadesca desenfreada". Op. Cit. In a different perspective, Mark Harris also analyzes the trajectory of some families from Pará and their importance in the politics. About this, see HARRIS, Mark. Op. Cit., p.81-91. military officers remain very high, with 16 and 14 respectively, this seems to be an exception. It is so that between the first 21 names indicated from Macapá, only three are among the elected to be part of the General Council, wherein the case of Rio Negro this rate reaches four. It is a very different picture from Cametá, one of the biggest electoral zones of the province. There, in 1828 , only one name identified as a military officer is among the most voted, less than the seven clerics and the two individuals classified as "doctorates". This trait seems to be predominant across the province, because between the 21 most voted names at Cametá, 12 were chosen to be part of the Council. This was also the same number of elected at Porto de Moz between the 21 most voted, zone where the number of military officers was also low. ${ }^{69}$

Finished the elections in 1828, the job of the General Council of Province began in November 28, 1829. On the first two annual meetings 1829/30 and 1830/31 the chairman was Antonio Correa de Lacerda, a figure until then known for being the president of the Governing Body elected during the Vintismo. It also draws attention the presence of Marco Antonio Rodrigues and Marcelino José Cardoso, two leaders of the coup d'état from August, 1831 that overthrew the president of the province the Viscount of Goiania. Among the most active, equally was the counselor Cônego Batista Campos, one of the characters arrested and deported to the countryside of the province because of the coup in $1831 .{ }^{70}$ Very active too was Silvestre Antunes da Serra that got to the role as a substitute. Serra became very known because of his actuation in Parás press that for a long time had been aligned with the positions of Batista Campos. Beside these, it had been elected Felix Antonio Clemente Malcher, political protagonist from the time of Independence and that posteriorly would be the first president of the province during the Cabanagem. Malcher, however, failed to take the role because he was under a lawsuit in the Council of War. Still composed this first Council João Marcelino Rodrigues Martins, Jacinto Francisco Lopes, João Batista Camecran, João Manoel Ribeiro, Antonio Manuel de Souza Trovão, Carlos Manuel de Alcantara, José Domingues de Serqueira, Francisco Pinto Moreira, André Fernandes de Souza, Francisco de Pinto Castilho, Agostinho Domingues de Serqueira, Manuel Otávio Prestes and Francisco de Elvas Portugal. Ambrósio Henrique da Silva Pombo was also elected but begged to be excused because he already was the president of the Chamber of Belém, in addition to this claiming that he was sick. His case is not discussed in the minutes, but the fact is that he does not assume the post. ${ }^{71}$

Besides counting with the presence of some of the several political characters from Pará since the Vintismo, the composition of the General Council also mirrored the presence of economically powerful families of the province. For example, starting from the considerations of Shirley Nogueira, it is possible to find here the Pombos and Elvas Portugal, pointed by her as families that enriched through their military ranks, something very common in this region and that often was related to the controlling of the Indian labor. Also in her description, the Carodoso had farms in Marajó and the Correa de Larcerda had thousands of heads of cattle. At the same time, it draws attention the absence of the Chermont, Moraes Bittencourt and Ayres, that according to Nogueira were among the major land owners and that had the wealth that was more linked to the agricultural economy, such as rice and cocoa plantations and cane mills. ${ }^{72}$

Although it had the participation of prestigious figures, during its 
Arquivo Público do Pará. Belém, Brasil. Códice 889, Atas do Conselho Geral de Província, sessões de $11,16,17,23,24$ de dezembro de 1829 e 05 de janeiro de 1830 .

74

Biblioteca Nacional. Rio de Janeiro, Brasil. MS602, doc. 17 - Atas do Conselho Geral do Pará, sessões de 23 e 26 de fevereiro de 1831.

75

SLEMIAN, Andréa. Op. Cit.

Arquivo Público do Pará. Belém, Brasil. Códice 889, Atas do Conselho Geral de Província, sessões de 07 de janeiro , 03 de fevereiro, 18, 20, 22, 23, 24, 29, 30 de dezembro de 1830.

77

SLEMIAN, Andréa. Op. Cit., p.193. first days the General Council of Pará lived with a contradiction: on one side it had a real effort from its members to provide it power, testing all its limits. This becomes much clearer with the many direct clashes of the counselors against the province's president. One of the most impressive occurred right at the first days of operation of the new agency, when it received a written representation against the recorder of the Chamber, Tristão Rangel de Azevedo Coutinho.

This was an ordinary matter in the Council, because it was frequent the reception of written representations from citizens or institutions complaining about the behavior of public servants in this agency. As it had made with in other cases, the counselors forwarded the question to the president of the province, the Baron of Bagé and demanded actions. However, on the contrary of other times, the president sent a harsh response saying that it was his own assignment and he would settle in his own way. The counselors then written a reply saying that they did not acknowledged authority in the province that could say which were the limits of their duties. The Baron of Bagé, in sequence, replied more aggressively, saying that it would not admit to receive mail about the matter anymore. Front to that, the Council decided to write about the matter directly to the Emperor, reporting the case. In addition to that they decided to make public their acts through a note in the Livro da Porta, what makes clear the concerns of the representatives to show to the people that the issues were sent. ${ }^{73}$

In 1831, the Council again had a clash against the province's president, now José Félix Pereira de Burgos, the Baron of Itapicuru-mirim. The counselors decided to write to the Parliament complaining about the fact that the president did not provided the requested information that were essential to make the projects of improvement of the province. More than a complain, the Council of Para wished for the Chamber and the Senate to express their views about the matter, saying that the local Executive Power was bound to give such information. ${ }^{74}$ In fact the local clash also mirrored the confrontation that already was happening in the Parliament between those who wanted so that the provincial presidents could be questioned by the General Council and those who disagreed with this vigorously. ${ }^{75}$

On the other side of the contradiction, on behalf of the concomitant occupation of other offices by the counselors, during many moments it becomes clear that the new agency still had less prestige than those most acclaimed. The extreme case was the already cited refuse from Ambrósio Pombo in taking office, under the plea that he already was the president of the Chamber of Belém. Although none had resigned from their posts of Counselors, it was many the occasions where the members of the Council justified their absences because of the necessity to attend to other agencies, such as the Chamber or the Presidential Council, occurring at various times the cancellation of the meeting because of the absence of quorum. ${ }^{76}$

This choice of the counselors is hard to understand, especially regarding the Chambers, because the law created in October, 1828 subordinate many of their actions to the Council, in a clear deflation of the old agency to the appreciation of the Provincial Powers. ${ }^{77}$ In the studied meetings, the stances of the Chamber from the city of Belém and many other towns were discussed in detail by the Council that not just authenticated it or not, but also did amendments to them. Thus the intrusion of the Council in the most common matters of the Chambers, such as the regulation of the commerce or the definition of penalties to those who did not 
PEREIRA, Vantuil. Ao Soberano Congresso: direitos do cidadão na formação do Estado Imperial brasileiro (1822-31). São Paulo: Alameda, 2010.

79

ANAIS do Parlamento Brasileiro. Sessões de 25 de setembro e 15 de outubro de 1830.

80

Ibidem. Sessão de 18 de setembro de 1830. light the lamps, was even greater than that of the Parliament regarding the Council, since the latter exercised the power to make amendments to the decisions that were made by the Chamber. Moreover, the stressful task of analyzing each point of the stances is one of the explanations for the low number of relevant propositions sent by the Council to the Parliament: of the 57 effectively realized meetings between November, 1829 and February 1830, 24 of them had as main agenda the discussion about the stances of Belém, reserving more four days for the debate about the stances of the towns of Óbidos, Melgaço, Cametá and Marajó. Furthermore, the very extension of the works of the Council, which should have ended in January, was justified by the president for not being able to finish the approval of the stances of the Chamber of Belém. As we can see the debate about the municipal stances was responsible for virtually half of the activities of the Counselors, which clearly hindered the elaboration of propositions about capital problems of the province.

Besides that, the prestige of the new institution could also be measured by the many petitions that were sent to them. They are complains about public servants, as the one already cited, allegation of application of unfair penalties, complaints about mistreatment or nonpayment and even request to increase the salaries. In the local level, the General Council seems to have occupied the role that Vantuil Pereira saw for the Parliament: the guardian of the constitutional rights. ${ }^{78} \mathrm{~A}$ role that, we highlight, is reinforced by the decision of the deputies to receive complaints of the Council about the members of the Executive and Judiciary Powers of the province, accused of despotism. ${ }^{79}$

Front to that, maybe the explanation that is left for the preference of some Counselors on occupying their jobs in old institutions is the difficulty to know what the resolution power of the Council was. This was a discussion even in the Parliament, where many representatives insisted that the Counselors could only suggest actions and nothing more. Many times this hit a wall for practical situations. For example, in one of their first actions, the Council wished to create a press to announce their minutes. There was a great discussion to make it possible, to the point of notify the president. In the end, it was decided to send this to the Parliament as proposition, describing even the staff needed and their salaries. The final answer of the Parliament was to refuse the proposition under the allegation that the Council did not have the privilege to create roles. ${ }^{80}$ In such situations certainly remained the impression that the Council had prestige, but very little true power.

The policy for the Indians debated in the General Council of Pará The evidence of the importance of the Indian question in Pará, among other things, manifests itself as the way this matter was recurrent amid the meetings of the General Council of Province, appearing in the debates of this institution in different ways. One of them was speeches of the provincial presidents that opened the annual meetings of the Council, whenever the topic appears, but always as a subtle matter, indirectly. Example is the speech of the Baron of Itapicuru-mirim in December, 1830. As the speech of the last year, the early focus was in the question of the labor and the production as one of the key themes of the province. In the first point indicated by him to be an object of meditation by the Council he discussed about the primitive men, saying that this condition could not remain. Supposedly supported by history, insists that the natural way was 
Arquivo Público do Pará. Belém, Brasil. Códice 889, Atas do Conselho Geral de Província, sessão de 01 de dezembro de 1830 . mola real das sociedades. Op. Cit., p.75-76. the civilization of the men and their subjection to the laws. The reference to the Indians of the province seems clear, as the linking of its civilization to the increase in the capabilities of the province. To this direction he insists that the abundance of resources of the province had made the men from that place little industrious, pleased merely with what was offered by nature. ${ }^{81}$ It is good to remember that it was precisely the so-called idleness of the Indians, featured by their satisfaction in supply themselves only with natural resources that justified since de Directory that the laws that forced them to the compulsory work. Particularly, this topic of the speech of the Baron of Itapicuru-mirim was a criticism target in the response made by a commission of Counselors composed by Batista Campos, his allied Cônego Serra, besides the counselor Alcântara. In this occasion, the commission refused to link the precarious situation of the province to what would be a tendency for idleness from its inhabitants, supposedly feed by the fertility of the province. On the contrary, they preferred to credit the low economical production, among other things, to the free will, saying that it were the good laws that stimulated the industrious men. ${ }^{82}$ Even if the Indigenist policy was not clearly called into question, it is very significant that this answer - that negates the natural tendency of the Pará people for idleness as the element for the absence of wealth in the province and make a complaint about the free will - had Batista Campos among their authors precisely because of some of his actions about the theme in the General Council, as we will see below.

As we said, the Indians were a recurrent subject and returned to the agenda in different ways. In this sense, in some occasions the Counselors demanded to the Government about the matter, showing that their intervention was not only made by propositions but also taking a stance of policing the Executive Power. This was the case when they demand data about the already cited conditions of the Milícias de Ligeiros, what would subsidize a written representation to the Parliament, which we will talk about later. In the same logic, in December, 1830, Batista Campos asked for the Council to demand that the President made public the "orders, attributions and instructions" related to the Indians that the Lt. Col. José de Brito Ingles and the Colonel Francisco Ricardo Zany were taking to the District of Rio Negro. ${ }^{83}$ This was not just any concern: Zeny was a wellknown character in the province. As mentioned in the early pages of this article, Zeny was the author of a project that were analyzed in the Courts of Lisbon that pretended to enlarge the exploration of the labor of the Indians, with greater control over the tapuios' labor and the license to perform slave raids on the forest people. ${ }^{84}$ Besides that, Zany was going to a territory where the presence of the tapuios was remarkable and the African uncommon. It also must be highlighted the fact that the request for clarification had as sole focus the Indians, not worrying about any other act that the two military officers could practice in the District of the Rio Negro. The action clearly aimed to constrain the Executive Power and the military and force them to make clear their policy about the Indians.

Beside the importance of the interventions and mentions above, without a doubt the actions of greater relevance of the General Council regarding the Indians were in the preparations and debating of the projects about the theme, even if their acts were restricted to the provincial sphere. In this sense, the first thing to be observed is the great quantity of submitted propositions: in the analyzed period it were discussed in the 
85

SALLES, Vicente. Memorial da Cabanagem:

esboço do pensamento político-revolucionário no Grão-Pará. Belém: CEJUP, 1992. p.62.
Arquivo Público do Pará. Belém, Brasil. Códice 889 Atas do Conselho Geral de Província, sessões de 24 de dezembro de 1829 e 05 de janeiro de 1830.

87

Ibidem, sessão de 15 de dezembro de 1830 .
General Council three propositions and one written representation about the Indigenist policy, certainly the matter that deserved most intervention from the Counselors.

In December 15, 1829, little more than 15 days after the beginning of the work, the first proposition made its debut. Presented by Batista Campos, the proposition required the end of the Fábricas Nacionais. As explained by Vicente Salles, Fábricas Nacionais was the given name to the institutions that organized extractive activities, especially wood, Brazil nut, rubber and cocoa, everything gathered through the compulsory work of the Indians. ${ }^{85}$ Sadly, it is not possible to know the contents of the original project because none of the propositions were transcript, only being able to understand the debate through the discussions of the amendments.

About the two amendments presented, besides some differences, both converge to the idea that would eliminate the Fábricas Nacionais, yet ensuring some exceptions. The very Council President, Antonio Correia de Lacerda, defended the extinction of the Fábricas Nacionais under the argument that they presented an unfair subjection of the Indians, but he required the keeping of the fishery and also that it could continue with the institution in places where the government could not gather wood. It also draws attention the fact that Lacerda proposed that the extinction of the Fábricas Nacionais not extended itself to the Rio Negro, precisely where happened to be a great concentration of tapuios. The justification was that this part of the province would become independent and should decide the matter later. As we can observe, the amendments pointed by Lacerda, even if they formally condemn the existence of the Fábricas Nacionais, they permitted exceptions and devices for the government that guaranteed the survival of the institutions. The other amendment, proposed by the Counselor Alcântara, had the same nuance of ensuring exceptions, requesting the keeping of the Fábricas devoted to gathering wood and, more precisely, the sawmill of Monte Alegre. ${ }^{86}$

This proposition, almost as the other ones related to the Indians, had a disappointing route: presented in the beginning of the works of the Council, in less than 20 days of project and the presented amendments had already passed by two of the three discussions needed to sanction the act. However, as far as the research went, this last discussion was never made. A year after its presentation, in December 15, 1830, it were created commissions to end unfinished business of the last year, being the project of extinction of the Fábricas Nacionais among them. ${ }^{87}$

How to understand that a project discussed so much still had not being finished and sent to the Parliament? Sadly, there is no final answer for this. Firstly it is truth that the agenda of the Council after the second discussion of this theme passed to be more and more taken by the debates about the Stances of the Chambers, which helped to paralyze the proceeding of the proposition. Even so it is good to remember that some propositions, even if few, could be finalized after this period. This makes us think that the central reason was the absence of agreement about such a delicate topic, that makes the act be forgotten inside the Chamber's drawer, as example of what constantly happened in the Parliament. Far from being a sole case, this seems to be the rule in the General Council of Pará: in the first term, despite projects about central themes of the province having been presented and discussed, it were few the propositions that could complete the entire course of action, be approved and sent to the Parlia- 
88

Arquivo Histórico da Câmara dos Deputados Centro de Documentação e Informação. Brasília - DF, Brasil. Lata 49, maço 21, pasta 1 - Lista dos trabalhos do Conselho Geral do Pará (1829-30). Look for MACHADO, André Roberto de A. As "reformas em sentido federal". A atuação dos representantes do Grão-Pará no Parlamento e as expectativas na província em torno do Ato Adicional. Revista Estudos Amazônicos, Pará, v.4, n.1, p.64, 2009. Except the four sent projects, it was also sent to the Parliament and to the Executive other texts, classified as resolutions, notes or with other titles.

89

In the text of the Viscount of Goiana that followed this annex, the former presidente of Pará affirmed that this practice had enriched some men from Pará that he called "wicked exploiters".

90

Arquivo Nacional. Rio de Janeiro, Brasil. IJJ9 - 108 - Ministério do Reino e Império. Pará, Correspondência do Presidente da Província (1829-31), doc. 328, anexo 15.

91

Ibidem, doc.328. Raiol transcribed part of this letter, also giving enormous emphasis to the end of the Fábricas Nacionais as one of the reasons for the fall of Goiania. RAIOL, Domingos Antonio. Motins Políticos. Belém: UFPA, 1970. p.228. ment. In fact, only four had been sent and all they were about peripheral themes, as the obligation of the foreign to present to the Judge of Peace at the maximum of three days after their arrival in the province, the installation of a public typography or the job dismissal for the Counselors that had public posts during the meetings. ${ }^{88}$ Other evidence that the problem was disagreement is that, as we will see, after the coup d'état in 1831 that deposed the Viscount of Goiania from the Presidency of the Province and arrested men of a more Liberal mind, the Council became to discuss a Project about the civilization of the Indians that followed the contrary direction of the proposal above, as it was the way until then.

The Fábricas Nacionais, however, seem to be a "hot topic" in the province. If it was not possible to finally find a project approved in the two first annual meetings of the Council, in 1831 they came back to the center of the public administration, now by the hands of the Executive Power and during the troublesome management of the already cited Viscount of Goiania as the President of Pará. In the end of July, 1831, a reunion of the Committee of Public Treasury takes place, also led by Goiania. In such occasion, they thought about the situation of the Fishery of Vila Franca and the Cocoa Plantation, two examples of institutions named as Fábricas Nacionais. The Committee, in first place, highlighted the few public gains of these projects and determined their extinction under the argument that it was a barbarian act against the Indians. The Committee mentioned that the Indians worked there compulsory, under gunpoint, with low salaries that went from 80 to 20 daily coins and that remained several years without being paid. ${ }^{89}$ Especially draws attention, however, the main argument to the end of these institutions: the Committee thinks that this "oppression should since long being end because they are contrary to the individual guarantees of the Brazilian people", adding to it in other part that this was an "ancient barbarism and contrary to the Constitution of the Empire".90 The importance here, beyond the extinction of these Fábricas Nacionais, is in those arguments, because they classify explicitly the Indians as citizens that had Constitutional rights and that were incompatible with such "ancient barbarism": the compulsory work. In other words, broadly speaking they repeated in this context the topic that questions the legitimacy of the forced labor of the tapuios since the Vintismo.

It is also important to have in mind that this was a decision of a collegiate and not only the president, what shows that the debate that was inside the General Council of Province, especially about the Fábricas Nacionais and about the Indians, was equally flowing inside other ways. Lastly, it is necessary to highlight that even if it was constituted as a bold act, the text of the Committee of Treasury suggests that only the cited Fábricas Nacionais would be extinct, the two unprofitable, and not the entirety. Then, this report and a complaint would be sent to the Court, from where apparently a decision was waited. Even if it weren't entirety clear the effectiveness of this action, in a long letter that was sent to the Court about his own version of the deposition from Presidency, the Viscount of Goiania insisted in mention the extinction of the Fábricas Nacionais - and from that we could understand that he was referring to every - as one of the main motifs for he being deposed of the presidency. ${ }^{91}$ In addition to demonstrate that the question of the Indian labor was a politically explosive matter in Pará, it is good to have in mind that one of the reasons alleged by the putschists to depose him was because Goiania was aligned 
Arquivo Público do Pará. Belém, Brasil. Códice 889, Atas do Conselho Geral de Província, sessões de $02,05,19,26$ de janeiro de 1830 to the positions of Batista Campos, precisely the member of the General Council of Province that had proposed, without success, the end of the Fábricas Nacionais.

Even during the first year of work of the Council, a second proposition emerged about the Indians question. On the contrary of the proposition made about the Fábricas Nacionais, this pretended to be a wider project for this population, but had a similar course as the first. Presented by the Counselor Carlos Manuel de Alcântara in January 02, 1830, it is also not possible to know its complete content, since the propositions were not transcribed, leaving space only for some notes to be taken from the few amendments presented. Apparently just from adapting a device that already existed, one of these amendments foresaw the figure of an Indian attorney that would be responsible to regulate the payment of these men. Thus it is possible to see again the centrality of the manpower in the issues that were related to the Indians. And, in addition to this, the intention of returning to the system of tutelage that had been shut down with the end of the Directory reappeared again, something that as we see until now was a recurrent attempt of the critical groups to what was considered by them as an excessive freedom of the "indios avilados" since the legislation of 1798. However, after passing down from the two initial discussions in January 26, the project was sent to a redaction committee and never went back to the plenary. Maybe an explanation to this is the fact that, beside the author, composed the committee Marcos Martins and Marcelino Cardoso, two leaders of the Agostada de 1831 that deposed the Viscount of Goiania from the presidency. ${ }^{92}$

In the middle of this process where the projects about the Indians discussed in the General Council could not achieve a final version to be sent off to the Parliament, it was other type of action that originated there and that ended having an effective impact in the Indians' policy, even if totally distinct of what had been the original proposition. In this sense, when we read the summary sent to the Court about the activities produced by the General Council of Pará during its first year, as we said before, there are only four projects included, but they still follow more than ten manifests, generally included as presentations. This was a common practice and often aimed to criticize or complain about other authorities, besides demand the decision of the Parliament about some matters. Thus it is a representation of the Council requesting the position of the Parliament about the Milicia de Ligeiros that could broke this blockade and arrive at the Court.

As said before, at the very beginning of their term it was ordered the information of the Presidency about the Milicia de Ligeiros, institution described in the previous pages of this article as one of the fundamental pieces for the recruitment of the tapuios for the compulsory work, as it was defined by the legislation of 1798 . The Council received this information with such speed and soon made a committee with a very significant composition: Batista Campos and his ally Cônego Serra complemented by the Counselor Jacinto Lopes Silvestre. Having this information, the committee made a little evaluation of this institution and proposed a feedback to be sent to the Parliament in the form of a representation.

Mentioning the information offered by the government the committee confirmed the continuity of the usage of the law of 1798 to oblige the Indians to the compulsory work, through the enrollment in the Milicas de Ligeiros. Batista Campos and the committee did not left any doubts about 
94

SILVA, João Nei Eduardo. Batista Campos: uma discussão biográfica na historiografia paraense. In: BEZERRA NETO, José Maia; GUSMÁN, Décio de Alencar (org.). Terra matura: Historiografia \& história social na Amazônia. Belém: Paka-tatu, 2002. p.139-149.

95

COELHO, Geraldo Mártires. Anarquistas, Demagogos e Dissidentes: a imprensa liberal no Pará de 1822. Belém: CEJUP, 1993. p.172 e p.255 ver também de MACHADO, André Roberto de A A quebra da mola real das sociedades. Op. Cit., p.157.

96

Arquivo Público do Pará. Belém, Brasil. Códice 869, doc. 03, em 20 de maio de 1828.

97

Ibidem. Códice 889, Atas do Conselho Geral de Província, sessão de 08 de fevereiro de 1830.

98

ANAIS do Parlamento Brasileiro. Em 8 de julho de 1830

99

Ibidem. Em 27 de novembro de 1830.

100

ANAIS do Senado do Império do Brasil. Em 18 e 26 de maio, 11 de junho de 1831. Coleção das leis do Império de 1831. Primeira parte. Rio de Janeiro: Tipografia Nacional, 1875. p.76. who were those enrolled in the Milicias de Ligeiros when they said that were the villagers of the Directory, confirming that besides the law of 1799 having extended the recruiting for white and black without occupation, ${ }^{93}$ in practice this was an onus for the so called "Christian Indians". As mentioned before, under the control of the military, it was created lists of the tapuios from the villages and the recruited were destined to the compulsory work in public and private works. Because of that, the control of this body was a decisive aspect in the province. The central point of the debate that moved committee was to prove, from some considerations about the legislation, that these Indians, although the organization having the name of Militia, should not be considered military, but yet an order. The sending of a question such as this one to the Parliament made entire sense, since the interpretation of the laws in that period was also up to this institution. As well observed by João Nei Eduardo da Silva, the reason for the feedback was not to end the Milicia de Ligeiros, but remove the control from the hands of the military and pass it for the civil power. ${ }^{94}$ The very text by the commission says that this body should be out of the "military privileges". Also this was not a new polemic: during the Vintismo the Committee of Civilian Government and the Arms Governor clashed about to what power should be the control over the Militia, a clash that even deserved manifests in the newspaper 0 Paraense..$^{95}$ In 1828, the Baron of Bagé, by time the Province President, wrote to the Minister of War, complaining that the Indians from the Militia were under the control of the military. ${ }^{96}$ For the rest, the very feedback gives the dimension of the importance of the Milícia de Ligeiros for the economy of the province and the organization of the society:

(...) Suits the public good and good administration of the Constitutional Government that the so-called Milicianos Ligeiros should be declared actual orders (...) for the end of the questions and conflicts between civilian and military authorities that since remote times entangle the march of the Government of Province and for the last to embrace with energy the most important branches of the Public Administration that cannot succeed in the actual condition because of complication of the military authorities with the civilian regarding the economic control of the said Indians; may well say that the province is a country purely military. ${ }^{97}$

Once sent to the Parliament, the discussion was fast and with a surprising end. In July 8 , the Committee of War of the Chamber summarized the major points of that representation and decided to ally with the interpretation sent by the Council. From the representation, they proposed a resolution where it would only became explicit that the Militias were not subjects to the Commander of Arms from the Province and, as so, end the clashes between the powers. ${ }^{98}$ However amendments were presented to this proposition. Between November 26 and 27, 1830, prevailed the substitutive amendments of the deputy from Maranhão, Odorico Mendes. In two articles of what was to be a legislative decree, Odorico Mendes just ordered the end of the Milícia de Ligeiros, abolishing every contrary device. ${ }^{99}$ Records about the debate were not registered, and the silence of the representatives from Pará is absolute. In the Senate, after the explicit condemnation by the Senator Saturmino, for which these militias were good only to exploit the Indians, the approval was very fast, and originated the transformation of the dissolution of the Milicia de Ligeiros by law of August 22, 1831. ${ }^{100}$

It was, without a doubt, a giant change in the politics of the Indians 
101

Arquivo Histórico da Câmara dos Deputados Centro de Documentação e Informação. Brasilia DF, Brasil. Lata 115, maço 16, pasta 4 - Província (acontecimentos de agosto de 1831 no Pará). Ata da Câmara de Alenquer em 26 de março de 1832

102

Biblioteca Nacional. Rio de Janeiro, Brasil. PR SOR 4750 - A Sentinella Maranhense na Guarita do Pará. Edição de 4 de outubro de 1834.

\section{3}

MACHADO, André Roberto de A. 0 Fiel da Balança. Op. Cit.

\section{4}

Arquivo do Instituto Histórico e Geográfico do Pará. Belém, Brasil. 105,6,23 - Coleção de proclamações, atas e outros impressos políticos relativos ao Pará entre 1827 e 1837 (doc. 3).

105

Arquivo Nacional. Rio de Janeiro, Brasil. IJJ9 - 108 - Ministério do Reino e Império. Pará, Correspondência do Presidente da Província (1829-31), doc. 328. in Pará because it would interfere in the main mechanism of recruitment of the so-called "Christian Indians" to the compulsory work in public and private works. The effective application of this change, their cheats and the possible impact of this in the conflicts that happened posteriorly in the Province are issues that need further researches. For now, however, it is possible to affirm that the information of the dissolution of the Milicia de Ligeiros had flowed through Pará at least since 1832 and that it were used as political capital by Batista Campos. So, in March, 1832, the minute of the Chamber of the town of Alenquer registered the request made by Batista Campos that it should be spread the end of the Milícias de Ligeiros through the publication of an edict. ${ }^{101}$ In 1834, in the newspaper "Sentinella Maranhense na Guarita do Pará", the publisher Lavor Papagaio listing what should have been the services made by Batista Campos, also mentions the extinction of the Milicia de Ligeiros. ${ }^{102}$ Even if we know through the crossing of the documents that this was not the original intention of Batista Campos, it is important to understand that the extinction of the militia was a matter of repercussion in the political life of the province.

Another important point to highlight is that Batista Campos require the advertisement of the ending of the Milicia de Ligeiros in a period where the political conflict in the province was more opened and more polarized. Few months before, in August, 1831, it happened a coup d'état that deposed the so president of the province the Viscount of Goiania. The Agostada, as this episode happened to be known, were a complex event which we already have written enough about, trying to comprehend its reasons and consequences. ${ }^{103}$ For the ending of this article, it should only be noted some points that help us think about their consequences for the General Council of the Province and for the discussion of the Indians policy within it. In first place, it is visible that the group that starred the deposition of Goiania had a more Conservative character and was frankly supported by an important portion of the military. In addition to that, the explicit motif for the coup, even in the letters sent to the Court was the proximity of the president with the political group led by Batista Campos. Even if the reality is more complex than that, about the questions linked to the Indians this observation finds some support. After all, as mentioned previously, Goiania ended with at least some Fábricas Nacionais, pretension that had previously appeared in one project made by Batista Campos and sent to the General Council. Not only that, it fell responsible to the managers of Goiania to apply a decision of the Parliament to put an end to the role of the District commanders. The ironic of all this is that it happened almost simultaneously to the failure of Batista Campos to approve something similar in the General Council. ${ }^{104}$ In such occasion, Campos defended the act as necessary because the commanders reduced the Indians to the condition of slaves. This point remembers much the posterior report that Goiania sent to the Court, when he listed the fulfillment of the law about the district commanders as one of the reasons for his fall. ${ }^{105}$ At last, thinking about its impact in the General Council of the Province and the debate about the Indigenist policy it is necessary to have in mind that the coup of 1831 implied not only in the deposition of Goiania, but also in the prison of many men considered connected to Batista Campos and their deportation to prisons within the province. This obviously altered the political equilibrium inside the General Council.

Precisely in this scenario of instability towards the most conserva- 
106

Arquivo Histórico da Câmara dos Deputados Centro de Documentação e Informação. Brasília - DF, Brasil. Lata 68, maço 37, pasta 4, Atas do Conselho Geral de Província, em 06, 07 e 29 de dezembro de 1831.

107

BAENA, Antonio Ladislau Monteiro. Representação ao Conselho Geral da Província do Pará sobre a especial necessidade de um novo regulamento promotor da civilização dos índios da mesma província. In: Anais da Biblioteca e Arquivo Público do Pará. Tomo 2, Belém: Imprensa Oficial, 1902

108

This was not the sole case in the Empire that the usage of Indians had been pointed as the solution to revert the effects of the end of the slave trade. For examples and a wider discussion, see SPOSITO, Fernanda. Nem cidadãos, nem brasileiros. Op. Cit. tive groups, one of the first acts to be discussed about the General Council of the Province was a Project of civilization for the Indians. Presented in December 6, 1831, the proposition did not come from a Counselor, but was sent by the Maj. Antonio Ladislau Monteiro Baena. Better known today by his works on statistics and about the history of the province, Baena was a Portuguese military who lived many years in Pará and was a great critical of the Liberals. The welcoming of the proposal made by Baena from this "new" General Council could not be any more explicit: at the second day, December 7, it is created a committee to evaluate the text with the orientation to utilize at maximum level the original text. Other surprisingly demonstration of the support of the Council for the proposition is that, when they received several requests from the Chambers of the countryside to send Indians to be engaged in different works, it is formulated an official answer that declared to be necessary to wait for the approval of the project made by Baena to regulate the offering of Indian manpower. ${ }^{106}$

On the contrary to other projects about the Indians that were presented in the Council, the text of Baena was preserved integrally, what help us to better comprehend his objectives. ${ }^{107}$ Already at its introduction, it becomes explicit that what moves the action of Baena is the preoccupation with the Indian manpower: after all, he points that the end of the slave trade - that he considers to be inevitable - made urgent the debate about a new plan of civilization for the Indians. ${ }^{108}$ At the same time, at the very beginning he insists that this was an opportunity to return to a route that has been abandoned: the tutelary regime of the Directory. The praise for the Directory and the critic of the law of 1798 are some of the pillars of the text and, as observed in the previously pages, echoed observations that were similar in projects previously drafted since the Vintismo. Moreover, in many moments he defends that his ideas are based in experience, supposedly using history as a topic for his train of though. Other important point to highlight is that the text made by Baena makes clear the expectation that the Province, through the General Council, had sufficient autonomy to impose a change in the politics about the Indians, revealing the prestige and the expectative that surrounded this institution.

Baena's project was divided in two parts: "Christian Indians" referring to those that already lived in the villages and "savage Indians", referring to those that were in the forests. The division, in first place, makes clear the importance of the Indians that were in the villages and that in Pará, as many assume for other regions, the civilization plans were not restricted to those that were out of the living with the white men. This division also exposed the two main objectives: for the "Christian Indians", resume the tutelage regime and so control its manpower. For the "savage Indians", resume the practice of the slave raids and thus bring new contingent of labors to the Province.

The control over the Indians and their obligation to labor were premises for the project of Baena. Using historical examples, he insisted that one of the greater errors was the law of 1755, which had given full liberty to the Indians before the establishment of the tutelage by the Directory, suggesting that this situation had made the province run out of workers, while the slave trade was still being stablished. Still during the introduction, it is very clear that by stating that when stablishing a new civilization plan, it should not let it fall into wrong points that preached against the "impelled work". Once more, recurring to history he says that the defense 
contrary to the compulsory work of the Indians was not sustained against the light of experience, returning to the old point of natural idleness of these people:
About the first proposition she is impugnable with the conclusive point that is experimentally acknowledged even by the Jesuits, yours most renewed catechists, that the inert hereditary idleness of the Indians that is for them the sovereign happiness, and their ineptitude to know and experience the comforts and incalculable benefits of the civil society prevent them from their own volition to search for regular work (...) therefore, they cannot be abandoned by themselves, but yet need to be guided by dispositions and rules of a contemporaneous compulsory controlling regime, which serving as diffuse or fundamental stimulant that reanimate their dead excitability and that turn them into useful agents and so adherents of the social life as other men. ${ }^{109}$

109

Ibidem, p.252.

110

Ibidem, p.271.

111

Ibidem, p.261.

112

Ibidem, p.260-262.

When talking about the "Christian Indians" the center of the proposition made by Baena is the description of this "controlling regime", that according to him, would last until the time the Indians already lived "accustomed to the art of making the existence happy searching for the benefits that the work and the industry can minister to them".110 Shortly, in each village would have a "Regent Patrolman" and above him a "Superintendent of the Indians", which would befall the regulation of the work, as the spatial organization of these men too. About this last aspect, it was predicted not only the suppression of the sparsely populated villages and the creation of new ones, but also the transit of the Indians passed to be controlled by the village authority, as saw at an old demand by the critics of the law of 1798. The text highlights the many activities that would be stimulated by the "Regent Patrolman", but owned by the Indians, coming to propose the donation of "little sesmarias" to these men. However, it is clear that every action, every work activity would be conducted by the Regent Patrolman and that he could punish those that do not fit together in the expected pace under the charge of vagrancy.

The recruitment mechanisms for the public and private works are not described in details, but appear mostly through the exclusion rules of this service. So it is said that the house leaders could not be removed from the villages to do other works, but could be obliged to "work for daily gains in the farms of Pará" if they did not support their families. ${ }^{111}$ Far from being just a punishment, in other parts of the text it became clear that it was up to the "Regent Patrolman" to provide manpower for both the public and private works. Thus it is shown that this authority should have the control of the Indians that were absent from the villages to provide services with their authorization and how much time they would be away. In other part it imposes that it should not exceed one third of the children of each family those that could be removed "for both the public service and for the owners of cane mill and crop plantations", emphasizing later that it still would be charged a tax from the salaries received by these Indians. ${ }^{112}$

In comparison to the number of pages destined to the "Christian Indians", Baena is much shorter when talking about the "Savage Indians". By itself this shows that the sensitive question for this military officer was the Indians that lived in the villages. However, there is still another question that reinforces this thesis: Baena defended the slave raids for new contingents of Indians that were in the forests, but on the contrary of the previous projects it did not intended that these men were distributed between 
the owners. Instead, the destiny of the "savage Indians" would be the villages where the "Christian Indians" had already been established under the regime of the "Regent Patrolman". This way these villages seemed to be the heart of the system by which Baena intended to regulate the labor of these Indians under a tutelage regime.

The proposition made by Baena, with the support of the Council after the Agostada, clearly tried to revert what seemed to be the progressive loss of institutions from the Colonial period that guaranteed the control over this manpower. Yet, as it happened with other propositions gestated in the Council, this never came to be implemented. The most plausible explanation is that with the tenure of office by Machado de Oliveira in 1832, the new province president sent by the Court and the return of the former Counselors the proposition faced resistances and was sent to limbo.

However the effective application or not of the Indigenist projects debated in the General Council is only one of the aspects that interests the historians. Most importantly than that seems to be the evidence that this was a central subject in the province to the point of receiving several projects and many discussions. Also the difficulties for the approval of the final propositions of these projects could not be credited to their low importance but rather to the difficulty of reaching a consensus in the Council about a matter that was vital and that would hit public and private interests. Lastly, when evaluating these projects and the debates in the General Council we light the central issue in Para regarding the Indians: all the projects, all the discussions had as major subject the control of the labor of these individuals.

Translated by Arthur Baltazar 